\title{
Left anterior descending artery percutaneous coronary intervention via the left internal mammary artery in a 54-year-old type 1 diabetic woman: a case report
}

Przezskórna angioplastyka gałęzi przedniej zstępującej z dostępu przez tętnicę piersiową wewnętrzną lewą u 54-letniej kobiety z cukrzycą typu 1 - opis przypadku

\author{
Radosław Kręcki, Jarosław Kasprzak \\ Chair and Department of Cardiology, Medical University of Lodz, Poland
}

Postep Kardiol Inter 2013; 9, 1 (31): 101-104 DOI: 10.5114/pwki.2013.34035

\begin{abstract}
Data on the treatment of left anterior descending artery (LAD) stenosis involving or localized distally to left internal mammary artery anastomosis are scarce and not homogeneous. Both surgery (CABG) and percutaneous interventions (PCI) have been attempted, but the most effective treatment has not yet been established. We report a case of a 54-year-old woman suffering from chronic, stable angina and diabetes type 1 successfully treated with percutaneous angioplasty of LAD via the left internal mammary artery with drug-eluting stent implantation with excellent short-term results.
\end{abstract}

Key words: percutaneous interventions, left internal mammary artery, diabetes type 1.

\section{Streszczenie}

Dostępna wiedza na temat terapii zwężeń w gałęzi przedniej zstępującej (GPZ), zlokalizowanych dystalnie w stosunku do zespolenia z tętnicą piersiową wewnętrzną lewą (left internal mammary artery - LIMA) oraz obejmujących to zespolenie, jest skąpa i niejednoznaczna. Podejmowano próby leczenia zarówno przezskórnego (percutaneous intervention - PCI), jak i kardiochirurgicznego (coronary artery bypass grafting - CABG), ale żadna z tych strategii nie uzyskała jednoznacznej przewagi. W pracy przedstawiono przypadek 54-letniej pacjentki z przewlekłą, stabilną chorobą wieńcową, z nasileniem dolegliwości do III klasy według CCS oraz z cukrzycą typu 1, leczonej metodą angioplastyki GPZ z dostępu przez LIMA, z objęciem zespolenia, zakończonej implantacją stentu uwalniającego lek.

Słowa kluczowe: angioplastyka wieńcowa, tętnica piersiowa wewnętrzna lewa, cukrzyca typu 1.

\section{Introduction}

There are insufficient data regarding the treatment of left anterior descending artery (LAD) stenosis located distally to its anastomosis with the left internal mammary artery (LIMA) or at the site of anastomosis. Percutaneous (PCI) and surgical (CABG) treatment attempts have been made, but none of these strategies showed a clear advantage.

\section{Aim}

We present a case of a 54-year-old woman with chronic, stable coronary artery disease (CCS class III) and diabetes type 1 treated with PCI of the LAD through the LIMA with anastomosis coverage and finished with drug-eluting stent (DES) implantation.

\section{Case report}

A 54-year-old woman with a history of coronary artery disease, diabetes type 1 (probably latent autoimmune diabetes in adults (LADA); the diagnosis was made at the age of 32 years) was electively admitted to the Department of Cardiology, because of worsening symptoms of angina (CCS class III). Medical history also included hypercholesterolemia. Coronary artery disease first manifested with STelevation myocardial infarction (STEMI) of the anterior wall 


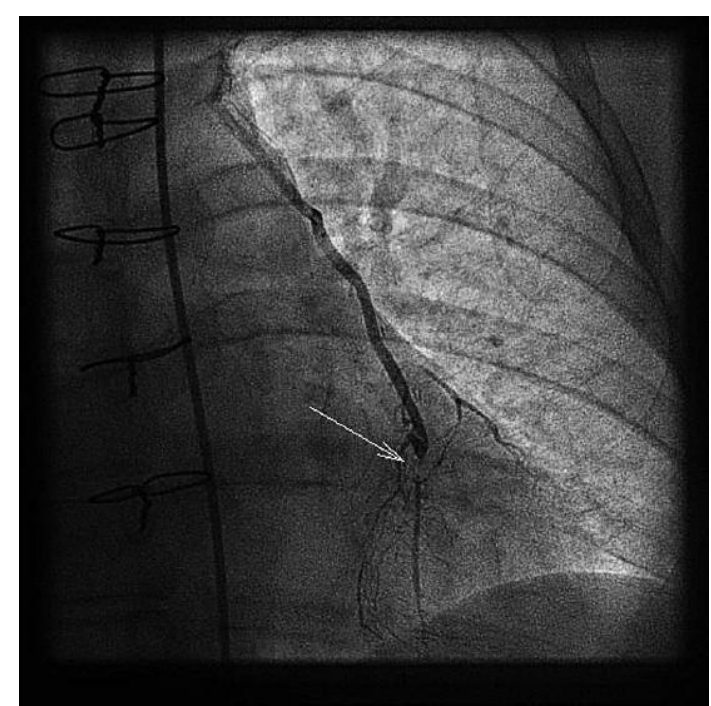

Fig. 1. 99\% stenosis of the left anterior descending (LAD) artery just below the site of its anastomosis with the internal mammary artery (arrow) - CRA 30

Ryc. 1. Zwężenie 99\% w gatęzi przedniej zstępującej (GPZ) tuż za miejscem wszycia tętnicy piersiowej wewnętrznej lewej (strzatka) - CRA 30

in 2005 (age of the patient at the time of the event was 47 years) and was treated with primary angioplasty of the LAD artery with bare metal stent implantation. Two years later, in 2007, the patient underwent coronary angiography due to worsening of angina symptoms to CCS class III. The examination documented marked progression of coronary artery disease with the presence of $99 \%$ restenosis at the site of bare metal stent implantation to the proximal LAD segment and significant stenosis of the right coronary artery (RCA) and circumflex artery (CX). Because of this clinical picture the patient was qualified for coronary artery bypass grafting. In 2007 the patient underwent an operation consisting of LIMA implantation to the LAD and implantation of saphenous vein grafts to the RCA and to the marginal branch. Because of the unsatisfactory control of glycemia $\left(\mathrm{HbA}_{1 \mathrm{c}}: 9.85 \%\right)$, intensification of therapy with insulin and regular monitoring by a diabetologist were recommended. At the beginning of August 2012 the patient was admitted to the Department of Cardiology again because of the worsening of angina symptoms to CCS class III, which was confirmed by the treadmill test leading to the onset of typical, severe angina pain at 4.6 METs load lasting until the second minute of recovery. Echocardiographic examination demonstrated regional systolic wall motion abnormalities with predominance of hypokinesis of the periapical $1 / 3$ of the left ventricle, which corresponded to the location of the previous myocardial infarction. Left ventricular ejection fraction was $54 \%$. Biochemical tests revealed a high level of glycated hemoglobin $\left(\mathrm{HbA}_{1 \mathrm{c}}\right.$ : 8.83\%), LDL cholesterol of $74 \mathrm{mg} / \mathrm{dl}$ (on $20 \mathrm{mg}$ of simvastatin) and creatinine level of $0.66 \mathrm{mg} / \mathrm{dl}$ (GFR: $105 \mathrm{ml} / \mathrm{min}$ ). Physical examination showed resting

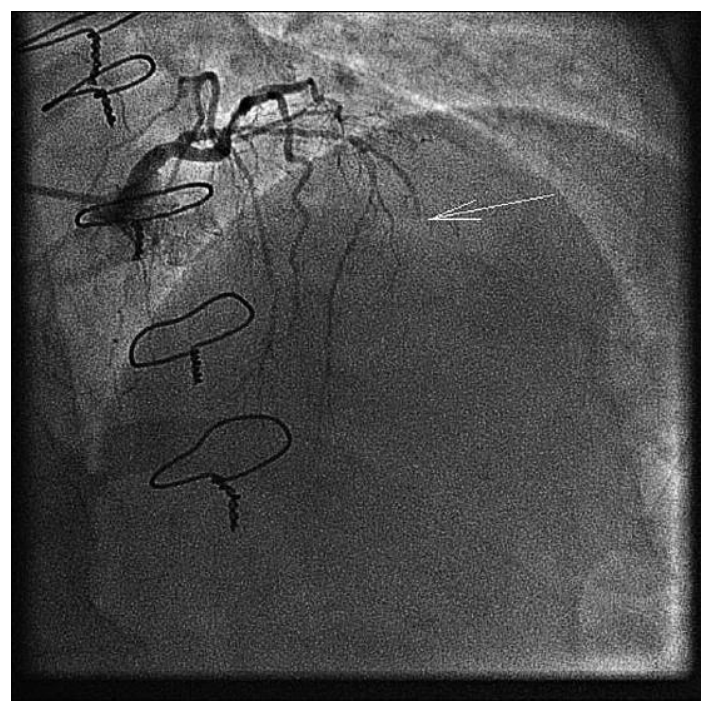

Fig. 2. Angiogram of the native left anterior descending artery after contrast injection to the left main stem - the vessel is amputated in the medial segment above the site of anastomosis with LIMA (arrow) - CRA 30, RAO 30

Ryc. 2. Angiogram natywnej gatęzi przedniej zstępującej z podaniem kontrastu przez pień lewej tętnicy wieńcowej-amputacja naczynia w segmencie środkowym przed miejscem wszycia LIMA (strzatka) CRA 30, RAO 30

heart rate of $85 / \mathrm{min}$ (on $2.5 \mathrm{mg}$ of bisoprolol). The patient was qualified for coronary angiography from transradial access, which showed both venous grafts amputated at the origin, distally occluded RCA and marginal branch with narrow distal segment supplied by the collateral circulation. The LAD was amputated in the medial segment and there was 99\% stenosis of the LAD located just below the site of its anastomosis with LIMA with impaired flow of contrast medium to the peripheries of the vessel (TIMI II) - Figures 1 and 2. Echocardiographic assessment using modern quantitative techniques clearly demonstrated the viability of myocardial segments supplied by the distal LAD [1]. According to guidelines the clinical decision was made by the "heart team" consisting of a cardiac surgeon, an interventional cardiologist and a treating physician (non-interventional cardiologist). Based on this decision the patient was qualified for percutaneous treatment of the LAD stenosis located below the site of anastomosis through the arterial graft and in case this would fail for re-CABG (EuroSCORE risk was estimated at 3.08\%). After obtaining informed consent and administration of clopidogrel (300 mg on the day before the procedure) the patient underwent angioplasty of the LAD with femoral access using an IM 6 F guiding catheter and the Pilot 50 angioplasty guidewire (Hi-Torque Guide Wire Pilot 50, Abbott) culminating in the implantation of a sirolimus-eluting stent $(2.5 \mathrm{~mm} \times 18 \mathrm{~mm}, 16 \mathrm{~atm})$. There was a very good angiographic result with improvement of 


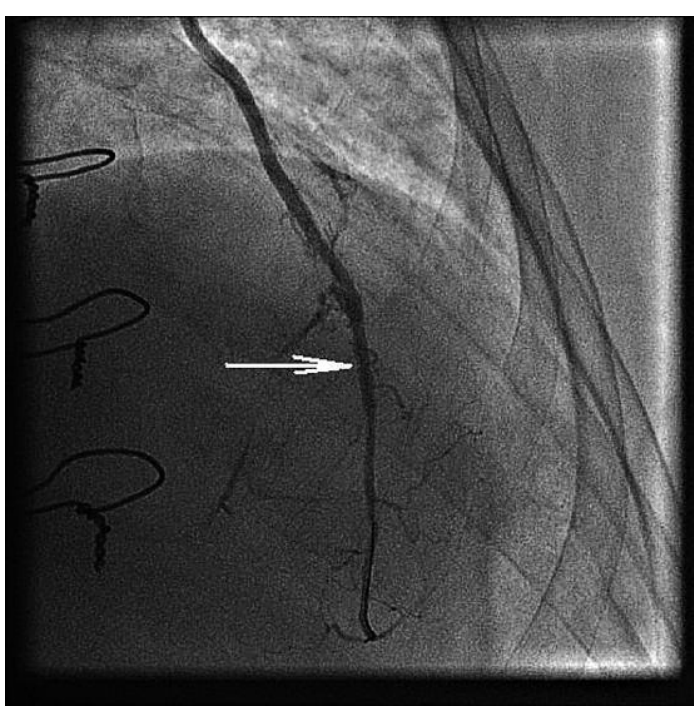

Fig. 3. Left anterior descending artery after angioplasty with DES implantation (arrow) filled with contrast medium injected through the left internal mammary artery - CRA 30

Ryc. 3. Gatąź przednia zstępująca po zabiegu angioplastyki z implantacją DES (strzatka) z podaniem kontrastu przez tętnicę piersiowa wewnętrzną lewa CRA 30

the blood flow to the LAD and through the network of collateral circulation to the diagonal branch and the right coronary artery (Figures 3 and 4). Wonderful effects of treatment were confirmed clinically by the results of a treadmill test performed at discharge, which was stopped at a load of 8.2 METS without the onset of chest pain or significant ischemic changes in the ECG. The patient was transferred to the Department of Diabetology for the modification of anti-diabetic treatment on the following medications: $10 \mathrm{mg}$ of bisoprolol, $10 \mathrm{mg}$ of perindopril, $40 \mathrm{mg}$ of atorvastatin, $150 \mathrm{mg}$ of aspirin, $75 \mathrm{mg}$ of clopidogrel (for 12 months minimum) and $50 \mathrm{mg}$ of isosorbide mononitrate.

\section{Discussion}

At first sight the case presented by us represents a problem of a worsening chronic coronary artery disease routinely diagnosed on cardiologic wards. However, the patient's medical history, angiographic presentation of atherosclerosis and the strategy of treatment developed by the "heart team" create a unique clinical situation. Remarkably accelerated atherosclerosis, early ACS and the whole history of coronary artery disease, which developed in a woman at a very young age (47 years old), are undoubtedly the result of long-term, poorly controlled type 1 diabetes (taking into account the age of diagnosis we are probably dealing with LADA type of diabetes mellitus). This is confirmed by very high values of $\mathrm{HbA}_{1 \mathrm{c}}$. Despite the efforts made in 2007 after cardiac surgery diabetes control improved only slightly, but remained far from ideal $\left(\mathrm{HbA}_{1 \mathrm{c}}: 8.83 \%\right)$, which is confirmed

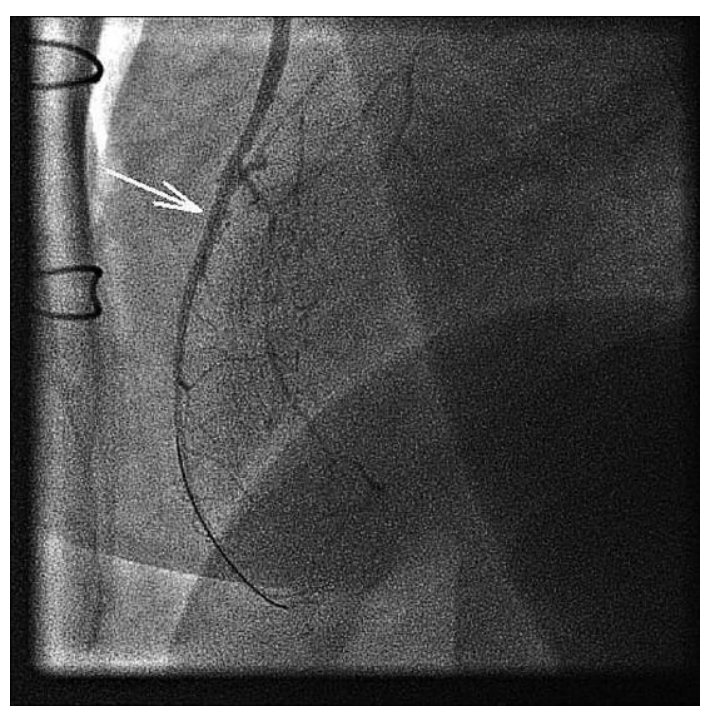

Fig. 4. Left anterior descending artery after angioplasty with DES implantation filled with contrast medium injected through the left internal mammary artery - LAO 90

Ryc. 4. Gałąź przednia zstępująca po zabiegu angioplastyki z implantacją DES (strzatka) z podaniem kontrastu przez tętnicę piersiowa wewnętrzną lewa LAO 90

by the coronary angiographic image. The dramatic progress of atherosclerosis leading to the occlusion of vein grafts and native coronary arteries with coexisting critical LAD stenosis located just below the site of its anastomosis with the internal mammary artery placed the patient in a high-risk group of cardiovascular events and reflected the severity of angina in the patient's daily life. Improvement of chronotropism and administration of other anti-anginal drugs would have certainly helped to control the symptoms, but total elimination of symptoms as expected by the patient was practically unobtainable. Despite the relatively low risk of reoperation (EuroSCORE 3.08\%) the consulting team of experts decided to treat the patient percutaneously with a possible conversion to $\mathrm{CABG}$ in case of $\mathrm{PCI}$ failure. The decision was based on the very unfavorable conditions for full anatomical surgical revascularization (very narrow peripheral segments of the right coronary artery and the marginal branch). Anatomical conditions such as good LIMA engagement from the subclavian artery with femoral access and direct course of the artery favored this decision. However, the location of stenosis just below the anastomosis (with the necessity of its coverage during stent implantation) increased the periprocedural risk above the average. Knowledge available in the literature on the treatment of LAD stenosis located distally to its anastomosis with the LIMA or including the site of anastomosis is scarce and ambiguous. Attempts are being made to treat these lesions percutaneously or surgically, but none of these strategies has shown a clear advantage, and anatomical diver- 
sity implies the need to make individual decisions [2-4]. In the present case, the $\mathrm{PCl}$ procedure was fully successful as demonstrated angiographically and clinically. Adequate treatment of diabetes is currently a key factor which can protect the patient from future recurrent cardiologic events.

\section{References}

1. Lipiec P, Szymczyk E, Michalski, et al. Echocardiographic assessment of myocardial viability at rest by speckle tracking technique - comparison with stress echocardiography. Pol Przegl Kardiol 2010; 12: 281-286.
2. Brilakis ES, Rao SV, Banerjee S, et al. Percutaneous coronary intervention in native arteries versus bypass grafts in prior coronary artery bypass grafting patients: a report from the National Cardiovascular Data Registry. JACC Cardiovasc Interv 2011; 4: 844-850.

3. Andrade PJ, Medeiros MM, Andrade AT, Lima AA. Coronary angioplasty versus CABG: review of randomized trials. Arq Bras Cardiol 2011; 97: e60-e69.

4. Zavalloni D, Rossi ML, Scatturin M, et al. Drug-eluting stents for the percutaneous treatment of the anastomosis of the left internal mammary graft to left anterior descending artery. Coron Artery Dis 2007; 18: 495-500. 